\title{
The Psychosomatic Basis of the Social Pedagogue's Behaviour
}

\section{Pavla Andrysová}

\begin{abstract}
This article aims to outline the possibilities and partially the content of psychosomatic preparation that results in the pedagogue's condition, which is understood to be the student's readiness to act authentically in open social situations. It also includes a comparison of two approaches concerning personal and social development of social pedagogy students.
\end{abstract}

Key words: psychosomatic preparation, psychosomatic condition, self-reflection, psychosomatic disciplines, social psychological training.

\section{Introduction}

In this article which is one of the outputs of GA ČR no. 406/09/1220 project (the project's name is "Determination and competence development of social pedagogues in professional preparation"), we would like to outline the aspect of social pedagogy students' education that involves personality development including its social dimension. This education is achieved through psychosomatic (non-object) disciplines. In the conclusion of the article we offer a comparison of two approaches, namely social psychological training as it is common practice, and psychosomatic preparation. 


\section{Psychosomatic disciplines}

In this place we would like to acquaint the reader with the contents of the individual psychosomatic disciplines as they are taught at the Department of Authorial Creativity and Pedagogy, The Theatre Faculty of the Academy of Performing Arts in Prague (DAMU) and as they have been transformed into the preparation of social pedagogues at the Department of Pedagogical Sciences, Faculty of Humanities, Tomas Bata University in Zlín.

The term psychosomatics is known especially as a medical term when doctors talk about psychosomatics, thus emphasizing the influence that the patient's mind has over his or her physical health. The conception of the psychosomatic approach as we understand it is the way that a person evaluates his or her existence as a physical and psychical unity. Any discipline that takes only one of the two factors to practice it as a sort of an instrument for a purpose is not considered to be psychosomatic. A psychosomatic discipline is therefore recitation and speech training, it is a dialogic action with the inner partner, as well as vocal training, movement training and author writing and reading (Hančil, 2005). The supporting pillar of this conception is a dialogic action with the inner partner. These disciplines develop psychosomatic condition.

\section{Picture 1}

The relation between psychosomatic disciplines

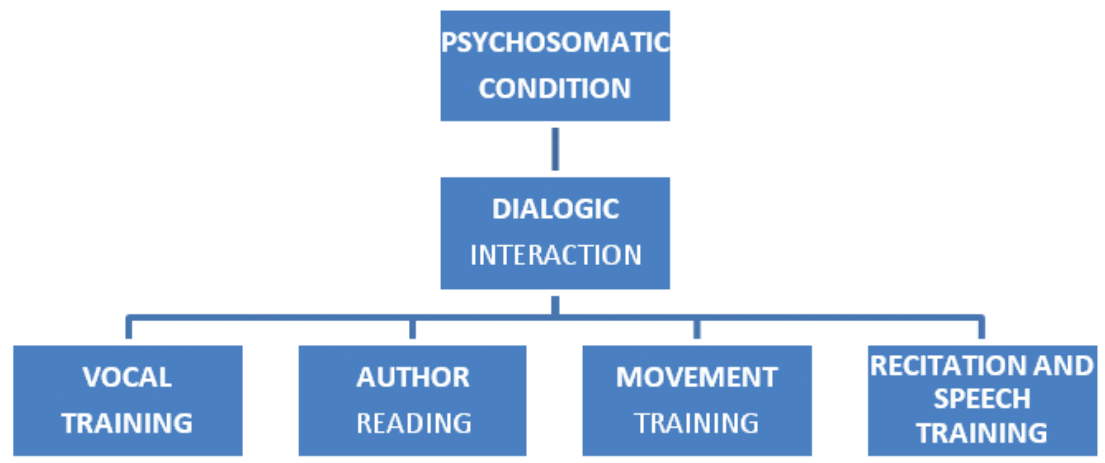

\subsection{Dialogic interaction with the inner partner}

The author of this specific form of dialogue is Professor Ivan Vyskočil. It is basically a dialogue of the individual with oneself when he or she has to capture the dynamics of his or her feelings using words, voice, movement, and other means. In the presence of 
the others one learns to be oneself. Dialogue should not be mere conversation, verbal replies, but real behaviour growing out of body involvement (Hančil, 2005).

The philosophic basis of this conception comes from the person who embarks upon the interaction he or she considers important with his or her whole human being. With his or her whole human being he or she acts and perceives. He or she has not developed some of his or her talents, and he or she has neglected the others. He or she comes back and again he looks for a personal "natural world" as Patočka (1995) calls it. He or she does this all concretely using his or her own body. Thus not merely in the area of guesses and words. The student focuses on things as a matter of course at first sight, and he or she is asked to reconsider, re-examine and re-acquire them on a more conscious and higher level.

As the cardinal meaning of this conception is education forming a creative and partner personality, it is not only about techniques for mastering voice, speech, movement, etc.; but it is about searching for a way of becoming and - with Fromm's verb - of being one's own voice, one's own speech, one's own movement, etc., of recognizing one's personality dispositions, accepting them, being in harmony with them, and developing them (Fromm, 2001).

The students are required to act for themselves as a matter of fact with their inner partner in a situation of public privacy. The participants are told to take their time, and to suppress their tendency "to be good".

The assignment for the one who starts to practise is always the same:

Try dialogic interaction with oneself. With oneself as a partner/partners. We all have an experience of this and anticipation of what and how it might be. So it is evocative of something that is known, but is often suppressed, or forgotten.

A dialogue in this approach means a soliloquy. Looking into the problem, topic, from at least two sides, checking out the alternatives. It advises us against the onesidedness of our views, bias, stereotypes, and old clichés. The opportunity to deliberate, discuss and act these things with the inner partner in a situation of public privacy, should lead to a better perception and ability to act openly and accept openly as well.

Should we use the terms from psychoanalysis, analytical psychology, or transactional analysis, both we and those in us can be Freud's Ego, Super-Ego, and Id in the conscious - unconscious mind, Jung's Self and Ego in the conscious, unconscious, and collective unconscious parts, Jung's Extrovert and Introvert, Berne's Parent, Adult, and Child, Perls'Topdog or Underdog. Or also Buber's Ich - Du, Ich - Es, or yin - yang and so on. For us: small - big, younger - older, clever - stupid, experienced - inexperienced, Don Quixote and Sancho Panza, Laurel and Hardy, etc.

The inner partner has our body and voice of a different tuning, different involvement, characteristics different from what we are when we enter the interaction. The human world is a world of meanings and relationships. Every A has its B, yes no, every question has its own not one and not pre-defined answer (Slavíková, 2005). 


\subsection{Author reading and writing}

As the integrating discipline is a dialogic interaction, then the author reading and writing connected with stage presentation acts as an output discipline. Vyskočil practises it in two forms: a collective seminar, or an individual activity. The basic model is very simple: the participant writes and Vyskočil gives him or her reflection. First the student has to write a story, then an essay, and an interview to better realize the principles and characteristics of these three genres, after that the students can write as he or she pleases. The requirement is the regularity of writing so that the participant tries to perceive and practise creativity, thought, and utterance as common option, so that this systematic activity creates promptness. What is unique is that within the seminar the text does not work as written, but solely as spoken. The author reads it to the others so he or she also becomes its listener, further is in the situation of direct communication and learns to formulate the text as utterance addressed to specific people in a specific situation, learns to find oral gesture, communicativeness, and contact. In the collective seminar every reading is followed by open discussion about the text and manner of utterance. The text is here primarily taken as an expression of latent bodily gesture and action. The students are deliberately discouraged from ambitions of being an artist, i. e. a writer in this case, but they are turned back to the primary communication (Čunderle, 2001).

\subsection{Recitation and speech training}

Vyskočil connects recitation and speech training - as another discipline taught in Department of Authorial Creativity and Pedagogy - to ethics and solidarity. He sets it (and other disciplines alike) apart from the context of art and puts it into wider and more primary human relations.

In the same way as in other disciplines, recitation also pays basic regard to the body. In accordance with the ideas of Emanuel Frynta, Vyskočil talks about speech as an oral gesture, as a bodily gesture proceeding in a gesture of speech. According to these tendencies, recitation or speech training is a domain of Vítězslava Fryntová who attended the same acting education as Ivan Vyskočil. She leads the student to learn to find maximum communicativeness and concrete of the text, to try to give it an authentic oral gesture, and to learn to talk to it - so that speech is really a means of communication and sharing. The dramaturgy of training texts of Vítězslava Fryntová is based on primarily spoken texts, with expressive oral gesturing, most of them are texts written in Czech: stories about law suits by František Němec, short stories by Jaroslav Hašek, Karel Poláček, Bohumil Hrabal, Frynta's poems, etc. However, for didactic reasons the training starts with e.g. social life catechism by Jiří Guth Jarkovský, or older cook 
books' recipes which are perfectly suitable to realize the basic logical structure and to create a concrete image of the communication.

\subsection{Vocal training}

We consider voice - whether in verbal or non-verbal form - an important medium that transcends us with its range and thus enables us to come out of ourselves and come back into ourselves and the others. The breath that puts rhythm into our action is not any less important either. Vocal training has been dealt with since the very beginning by docent Libuše Válková.

While thought and written word activates human intellect, spoken word puts into the communication not only intellect but also body. Singing expresses immediately experienced and felt state of human psychosomatic basis in relation to the world, environment, concrete human situation and existence. Moreover, singing utterance is a sound quality and also an utterance of psychosomatic harmony. At the same time it is a demonstration, embodiment of relaxation and health, quality of the individual's organism.

There is a connection, causality between voice and personality; voice cultivation has a depth - in its impact still not appreciated - meaning for the psychological development of a person. Vyskočil says: "Without a voice one does not have a personality. With an impaired voice one also has one way or another impaired psyche. One is not freely oneself." And Válková (2000) adds: "A speaker makes sounds out of the spirit of the language, while a good singer forms sounds bodily."

\subsection{Movement training}

The aim of movement training is to reach understanding when body and movement is able to reflect thought precisely and multi-dimensionally. When the individual uses it to support and multiply the effect of one's verbal utterance or to express diverse relation to one's dialogue with the partner. Body language develops its own "text", turns the utterance upside down, and so on. It is incorporated into the overall situational context with nonverbal action and thus it fully involves the whole body.

Movement training started in the 1970s at elementary schools of art where it was taught by Milena Moravcová, the arrival to DAMU began a more constant cooperation with Zdenka Kratochvílová and Eva Kröschlová. Generally speaking, the desired aim of this training is to awaken spontaneity and creativity of one's own body, to set it free from automatic stereotypes and to return to the primary bodily existence (Čunderle, 2001). 


\section{Psychosomatic condition}

By way of these disciplines, one comes to psychosomatic condition. One tries and discovers the potential of oneself in the presence of the others, without unnecessary fears of embarrassment because mistake is here viewed as natural part inevitable either at school or in everyday life. According to Vyskočil it is: "a kind of maturity, readiness, promptness, and sometimes also a need, fancy, drive to perform, act, behave, experience in public in a direct, immediate, spontaneous, creative, and productive way, freely and responsibly" (Vyskočil, 2000, p. 7).

Psychosomatic condition which can be defined as "capability" or "promptness" is no doubt one of the benefits of psychosomatic disciplines, but if these are (viewed from the final perspective) Fink's "Oasis of Happiness", they are definitively not Eden of Ease. In psychosomatic disciplines, joy is born of trying and searching regardless the immediate result. Often condition is built and its level tested not in successful moments but in times when you are "banging your head against a brick wall" and manage to change this difficult situation into an easy one.

Condition is formed on the basis of repetition and is the real result of the discipline. Just because of condition hidden reserves mobilize in a person at the right time and enable one to come through a difficult situation safely (Hančil, 2005).

The study of these psychosomatic disciplines is reflected in detail by the teacher as well as the participants. This ubiquitous self-reflection teaches the person receptivity to oneself so that one can achieve one's real authentic being.

\section{A comparison of social psychological training and psychosomatic disciplines}

One of the requirements that an individual is expected to do during this preparation is keeping a self- reflection diary. These reports usually take the form of personal accounts or commentary on current state, on the way the participant experiences the lessons of the psychosomatic preparation, what new things he or she learns and realizes, and what new potentials of his or her development the participant sees.

The aim of these reports is besides other things, the development of the ability to ask and answer questions relating one self, other people, events and activities.

These self-reflective reports are a prerequisite of all psychosomatic disciplines. According to Švec (2007) self-reflection is a part of cognition and learning, it is the basis of self-regulation of the participant's activities. Self-reflection that is written down is the "memory" of the participant's experiences, feelings and what he or she deduces from this knowledge. However, it is not only self immersion, not only introspection, but it is 
also a view of the future, it means the awareness of how I am able to keep improving my capability, or condition.

In the following table we will try to compare two approaches - namely the common social psychological training and psychosomatic disciplines. The given categories and conclusions come from the content analysis of students' self-reflection diaries that they kept during the whole time of preparation.

Table 1

\section{A comparison of social psychological training and psychosomatic disciplines}

\begin{tabular}{|c|c|c|c|}
\hline Category & Social psychological training & Psychosomatic disciplines & $\begin{array}{l}\text { Statements } \\
\text { in the students' diaries }\end{array}$ \\
\hline Rules & $\begin{array}{l}\text { They are given in advance, which } \\
\text { keeps the person within close } \\
\text { bounds, it restricts the student to } \\
\text { the things that are focused on. The } \\
\text { person is thus lead through the } \\
\text { training rather than finding one's } \\
\text { own way. }\end{array}$ & $\begin{array}{l}\text { Almost none. The person thus gets } \\
\text { almost infinite space for searching } \\
\text { one's own topic. Important } \\
\text { factors are personal maturity and } \\
\text { experience. It also takes a lot of time } \\
\text { and internal motivation from the } \\
\text { students. }\end{array}$ & $\begin{array}{l}\text { *SPT: 1) There are given rules, at any cost you } \\
\text { have to answer the question or assignment } \\
\text { you get. In a certain way limited, closed. } \\
\text { **PSD: 1) There are no limits given, you } \\
\text { can do what you want. I experienced a lot } \\
\text { of feelings (embarrassment, agitation, } \\
\text { indifference). }\end{array}$ \\
\hline Communication & $\begin{array}{l}\text { Frequent group or pair work, } \\
\text { therefore the necessity to } \\
\text { communicate with other members } \\
\text { of the group. This has been aimed } \\
\text { at since the pre-school age and it } \\
\text { is surely important, however, it is } \\
\text { nothing innovative. }\end{array}$ & $\begin{array}{l}\text { The emphasis is put on discovering } \\
\text { communication with one's own self } \\
\text { (one's inner partner/partners), which } \\
\text { can understood as a new dimension. } \\
\text { This confirms the presumption } \\
\text { that we often cannot be one's own } \\
\text { partner. Now the students are } \\
\text { wanted to search for the meaning } \\
\text { of the utterance, slow down, take } \\
\text { notice of the somatic tension, which } \\
\text { is often new and difficult. }\end{array}$ & $\begin{array}{l}\text { SPT: 1) I had to talk it out in a group. 2) There } \\
\text { is more work in groups. } \\
\text { PSD: 1) I use facial expressions to deeply } \\
\text { express the feelings in the given text. }\end{array}$ \\
\hline Self-knowledge & $\begin{array}{l}\text { Considering the self-knowledge } \\
\text { activities the students reflect that } \\
\text { they do not learn anything new } \\
\text { about themselves. }\end{array}$ & $\begin{array}{l}\text { The students claim that in the } \\
\text { situations of "searching the inner } \\
\text { partner" they naturally and better } \\
\text { learn about themselves. They are } \\
\text { well aware that they cannot help } \\
\text { other people unless they know } \\
\text { themselves sufficiently. }\end{array}$ & $\begin{array}{l}\text { SPT: 1) I gave a true description of myself; } \\
\text { however, I do not know whether I learned } \\
\text { anything new about myself, quite possibly } \\
\text { not. 2) Most people were sincere to } \\
\text { themselves, at least I think so, but I wasn't, } \\
\text { it is too difficult for me. } \\
\text { PSD: 1) I felt a bit uncomfortable. I didn't } \\
\text { know what to do with my own movements. } \\
\text { 2) I'm much more self-aware when I have } \\
\text { to deal with myself in front of other people. } \\
\text { 3) You saw it on your own how you act in } \\
\text { various situations. 4) You don't have to } \\
\text { pretend. 5) Some of us don't want to talk } \\
\text { about themselves much, but the interaction } \\
\text { makes them to. 6) I am more aware of my } \\
\text { movements and my voice. }\end{array}$ \\
\hline
\end{tabular}




\begin{tabular}{|c|c|c|c|}
\hline Category & Social psychological training & Psychosomatic disciplines & $\begin{array}{l}\text { Statements } \\
\text { in the students' diaries }\end{array}$ \\
\hline Responsibility & $\begin{array}{l}\text { As for feelings, the students reflect } \\
\text { more relaxation, but also less } \\
\text { responsibility = less effort. The } \\
\text { students do not feel responsible } \\
\text { for their solutions because they } \\
\text { sense the unreality of the situation. } \\
\text { They react to the artificially created } \\
\text { situation by an artificially created } \\
\text { reaction for which they do not bear } \\
\text { so much responsibility. They are just } \\
\text { having a good time. }\end{array}$ & $\begin{array}{l}\text { The fact that "I have to rely on } \\
\text { myself only" tends to create more } \\
\text { nervousness and tension, but at } \\
\text { the same time it produces more } \\
\text { responsibility for one's behavior. } \\
\text { Author reading makes the students } \\
\text { realize more responsibility for the } \\
\text { communicated content, they want } \\
\text { to argue what they wrote and then } \\
\text { read. By reading their text they want } \\
\text { to attract attention of the others, } \\
\text { they take care of its interpretation. }\end{array}$ & $\begin{array}{l}\text { SPT: 1) It was up to me what I say or do, less } \\
\text { responsibility = less effort. 2) I liked it. It was } \\
\text { fun. I had a good time. } \\
\text { PSD: 1) When I read my own text, I feel } \\
\text { responsible for its content. 2) I try to read in } \\
\text { such a way so that it is an experience for the } \\
\text { listeners; I do not read it for myself but for } \\
\text { them. 5) I take the trouble to write the text, } \\
\text { so I stand for it. I want to deliver a message. }\end{array}$ \\
\hline $\begin{array}{l}\text { Creativity } \\
\text { Relates to Rules }\end{array}$ & $\begin{array}{l}\text { The students reflect that they } \\
\text { do not have to invent anything } \\
\text { new, unless they want to, so they } \\
\text { simply follow the instructions. They } \\
\text { understand the instructions as a sort } \\
\text { of boundaries. }\end{array}$ & $\begin{array}{l}\text { The situations themselves which are } \\
\text { not limited by the instructions, make } \\
\text { the students act spontaneously and } \\
\text { feedback creatively. The awareness } \\
\text { of the emphasis on now and } \\
\text { here parallels the work of social } \\
\text { pedagogue and helping professions } \\
\text { in general. The confirmation of the } \\
\text { fact that if the person does not have } \\
\text { precise instructions for the activities } \\
\text { undertaken, then one has to act } \\
\text { creatively. }\end{array}$ & $\begin{array}{l}\text { SPT: 1) If I don't want to, I don't have to } \\
\text { think too much and just stay within limits. } \\
\text { 2) I miss inspiration; at any cost you have to } \\
\text { answer the question or task you get. 3) I do } \\
\text { the assignments in the same way even after } \\
\text { a long time pause. } \\
\text { PSD: 1) I do the assignments in psychosomatic } \\
\text { disciplines differently each time. 2) I could } \\
\text { use creativity. 3) It hindered me much less } \\
\text { because there is less stuff that I have to } \\
\text { stick to. }\end{array}$ \\
\hline
\end{tabular}

ŘlHÁK, T. Komparace př́stupů v rámci osobnostně sociálního rozvoje studentů sociální pedagogiky. Bakalářská práce. Zlín: UTB, 2011.

*SPT = Social psychological training, ** PSD = Psychosomatic disciplines

We are aware that the results shown here cannot be generalized. What is essential for us is the knowledge of the fact that both approaches have their place and reason and they can supplement each other. Yet, it would be interesting to determine whether the typology of the student's or participant's personality has any influence on the preference of the one or the other of the given approaches. And if, or how much, this choice is influenced by personal maturity and life experience. A general overview of these issues was published by Chudý, Š., Jůvová, A. \& Neumeister, P. (2011).

\section{Summary}

The personality development has been a natural part of all social psychological trainings for a long time; however, in our approach we intended to draw attention to the often ignored psychosomatic dimension in its unity that we understand to be the essential part which cultivates personality in its integrity. If we are to prepare social 
pedagogues who should be able to help their clients, then it is necessary to prepare not only erudite experts but also strong personalities that have a partner relationship with themselves, since a mature personality is a personality capable of creating relationships, which we consider to be one of the key competences not merely within the scope of social pedagogy studies.

\section{References}

Čunderle, M. \& ROUBAL, J. (2001). Hra školou. Dvakrát o Ivanu Vyskočilovi. Praha: Nakladatelství Studia Ypsilon.

Fromm, E. (2001). Mít, nebo být? Praha: Aurora.

Hančil, J. (2005). Otevřený svět dialogického jednání. In Vyskočil, I. et al. Dialogickéjednánís vnitřním partnerem. Brno: JAMU.

Chudý, Š., Jůvová, A., Neumeister, P. et al. (2011). Vybrané diskurzy teorie a praxe ve vzdělávání a uplatnění sociálních pedagogů v kontextu pomáhajících profesích II. Brno: Paido.

Patočka, J. (1995). Tělo, společenství, jazyk, svět. Praha: OIKOYMENH.

Říhák, T. (2011). Komparace prístupů v rámci osobnostně sociálního rovoje studentů sociální pedagogiky. Bakalářská práce. Zlín: UTB.

Slavíková, E. (2005). Dialogické jednání z poznámek asistenta. In Vyskočil, I. et al. Dialogickéjednání s vnitřním partnerem. Brno: JAMU.

Švec, V. (2007). Psychosomatické základy ve studiu sociálních pedagogů. In Sociální pedagogika $v$ současné společnosti. Zlín: UTB.

Válková, L. (2000). K psychologickým aspektům výchovy k profesionálnímu hlasovému a zpěvnímu projevu. In Psychosomatický základ veřejného vystupování jeho studium a výzkum: sborník z konference 14. a 15. řijna 1999. Praha: AMU.

Vyskočil, I. (1999). Úvod. In Psychosomatický základ veřejného vystupování jeho studium a výzkum: sborník z konference 14. a 15. řijna 1999. Praha: AMU.

\section{Contact:}

Mgr. Pavla Andrysová, Ph.D.

Tomas Bata Univerzity in Zlín

Faculty of Humanities

Department of Pedagogical Sciences

nám. T. G. Masaryka 1279

76001 Zlín

E-mail: andrysova@fhs.utb.cz

Phone: +420 576038025 